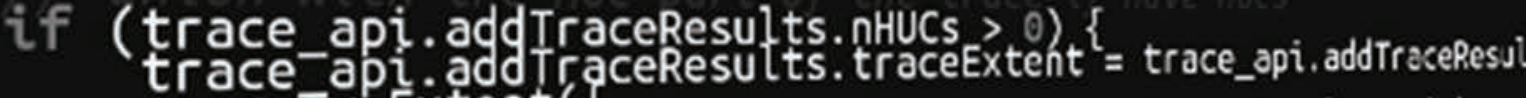
new Extent (

\title{
Data and Spatial Studies of the USGS Texas Water Science Center
}

\section{Introduction}

Hydrologists, geographers, geophysicists, and geologists with the U.S. Geological Survey (USGS) Texas Water

Science Center (TXWSC) work in the USGS Water Mission Area on a diverse range of projects built on a foundation of spatial data. The TXWSC has developed sophisticated data and spatial-studies-related capabilities that are an integral part of the projects undertaken by the Center; these capabilities include

- Web design, mapping, and services

- Computer programming/custom tool development

- Hydraulic, hydrologic, and groundwater modeling

- Data mining and statistical analysis

- Database development and data management
- Spatial data production, analysis, modeling, and visualization

- Watershed delineation and characterization

- Publication-quality cartography

- Land cover/land use mapping and analysis

The following are a few examples of USGS work incorporating programming, modeling, and spatial analysis to facilitate scientific studies in Texas and throughout the Nation; most of the projects incorporate several different data and spatial analysis capabilities. The descriptions of project-specific activities are presented including project images, Web links, and Quick Response (QR) codes that can be followed to obtain additional project information and related publications, articles, and datasets.

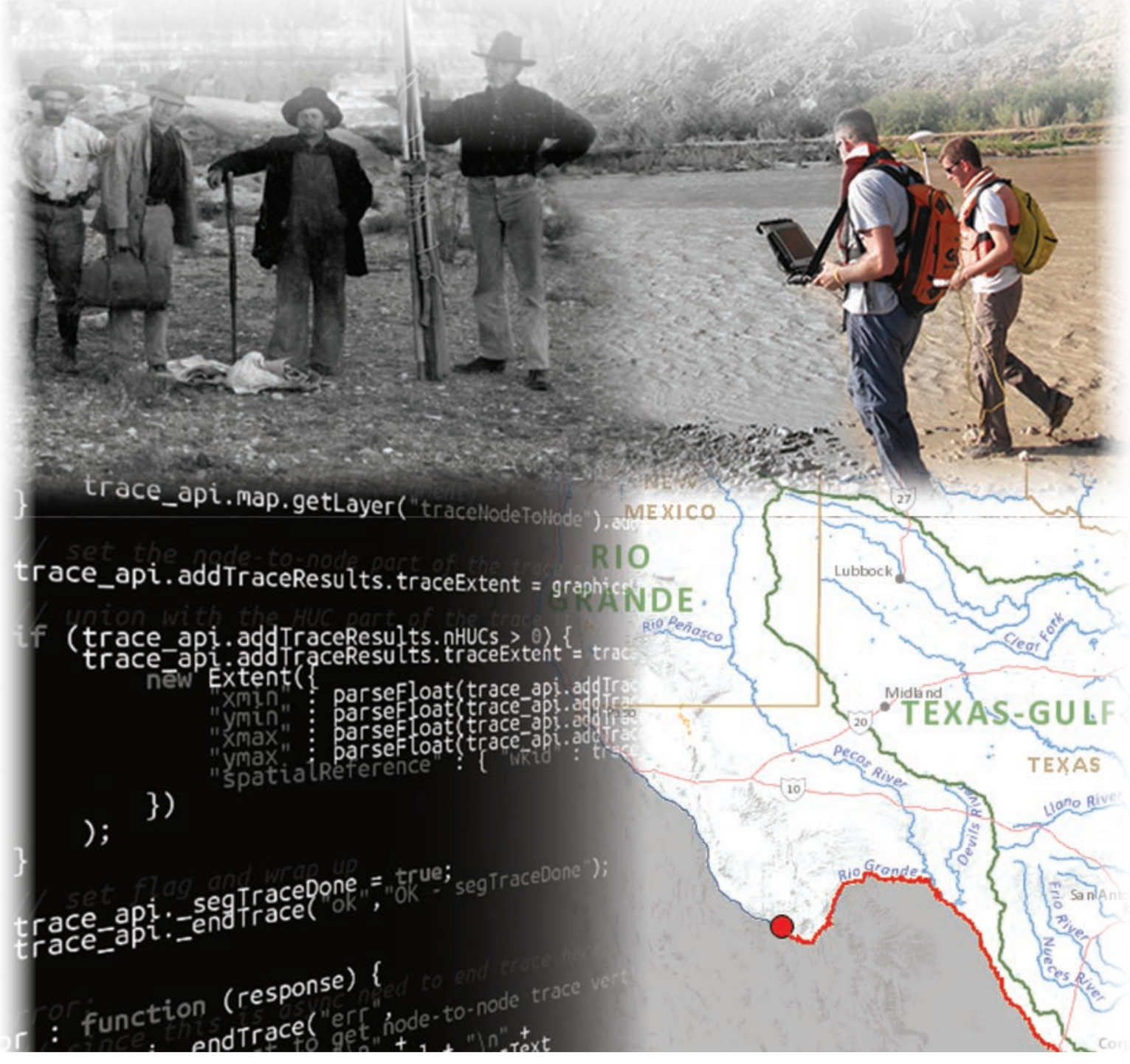




\section{Walker Basin Hydro Mapper}

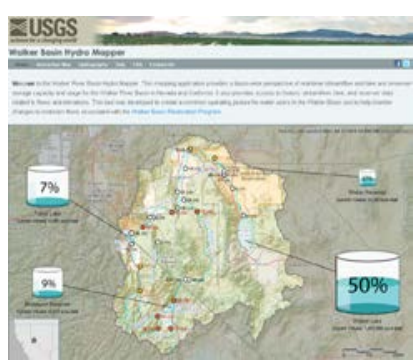

In cooperation with the Bureau of Reclamation and the National Fish and Wildlife Foundation, the USGS produced the Walker Basin Hydro Mapper, an interactive map and Web site for showing a visual and quantitative summary of daily and historical streamflow conditions and waterbody storage in the Walker River Basin in Nevada and California. The purpose of the Web application is to provide a common tool for water users in the Walker River Basin and to help monitor changes to instream flows associated with the Walker Basin Restoration Program.
- USGS Web application: http://nevada.usgs.gov/ walkerbasinhydromapper/

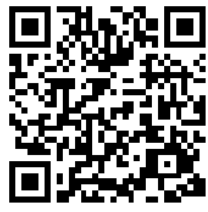

\section{Streamer}

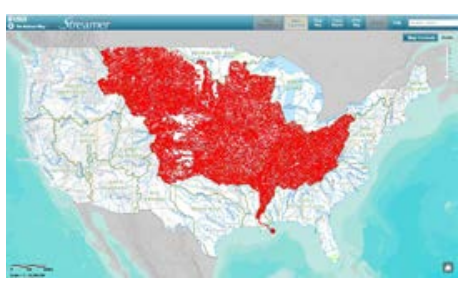

In cooperation with the National Atlas of the United States and the National Map, the USGS produced Streamer, a Web-based mapping application for tracing major rivers in the United States upstream and downstream. Streamer uses digital hydrographic data for the United States at a 1:1,000,000 scale. Additional features include search and identify tools, locations of USGS streamflow-gaging stations symbolized with near real-time streamflow data, weather radar, a choice of base maps, and an option to generate a report with a map of the trace and descriptive information about the area covered by the trace.
- USGS Streamer Web application: http://nationalmap.gov/streamer/

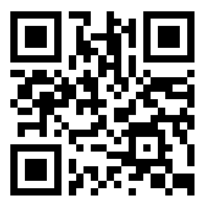

\section{myScience}

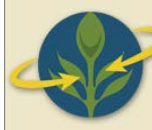

\section{myScience} connecting people to science
The USGS is continually striving to find new ways to engage the public in its scientific research. The TXWSC helped to develop the myScience public engagement and project discovery Web-based application as a way to engage the public. Questions that the myScience application helps to answer include

- What science projects that encourage public participation in scientific research are active within the USGS?

- How can members of the public support and participate in projects featured on the myScience Web application?

The myScience Web application addresses these questions by enabling open, public access to USGS citizenscience project information.
- USGS myScience Web application:

http://txpub.usgs.gov/myScience/

\section{NWIS Web Services Snapshot Add-In for ArcGIS}

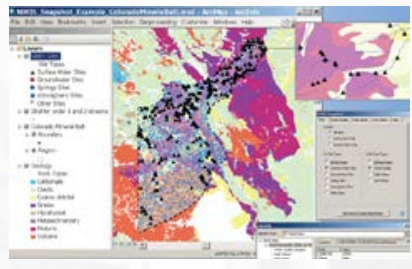

The National Water Information System (NWIS) Web Services Snapshot Tool for Esri ArcGIS enables rapid access to NWIS, the USGS database that contains hydrologic information for more than 1.5 million surface-water, groundwater, and atmospheric monitoring sites throughout the United States, including many with periods of record that began more than 100 years ago. The NWIS Web Services Snapshot Tool helps scientists to efficiently explore hydrologic data within the Esri ArcGIS framework. Design and functionality of the NWIS Web Services Snapshot Tool are driven by the data integration and management needs of USGS scientists to answer questions about hydrology, hydrogeology, climate, the environment, wildlife, and other integrated science topics.
- USGS NWIS Web Services Snapshot Tool: http://txpub.usgs.gov/snapshot/

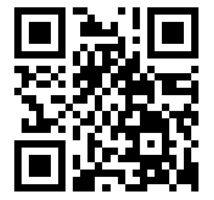

\section{Simulation of Streamflow and the Effects of Brush Management on Water Yields in the Upper Guadalupe River Watershed, South-Central Texas, 1995-2010}

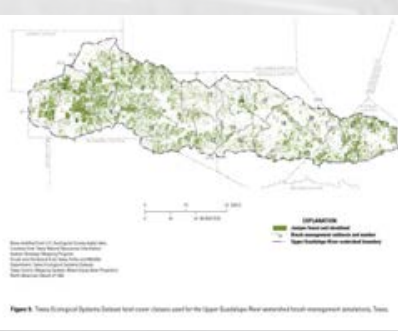

The USGS, in cooperation with the Texas State Soil and Water Conservation Board and the Upper Guadalupe River Authority, developed and calibrated a Soil and Water Assessment Tool (SWAT) watershed model of the upper Guadalupe River watershed in south-central Texas to simulate streamflow and the effects of brush management on water yields in the watershed and to Canyon Lake for 1995-2010. Model development was driven by semiautomated spatial analysis workflows to generate sophisticated model input datasets. Model simulations quantified potential changes in water yield from individual subbasins in the upper Guadalupe River watershed in response to replacement of Juniperus ashei (Ashe juniper) with grasslands. The simulation results will serve as a tool for resource managers to guide brush-management efforts.
- USGS publication: http://pubs.usgs.gov/ sir/2012/5051/

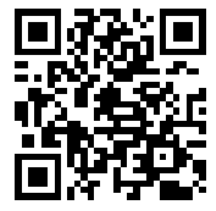




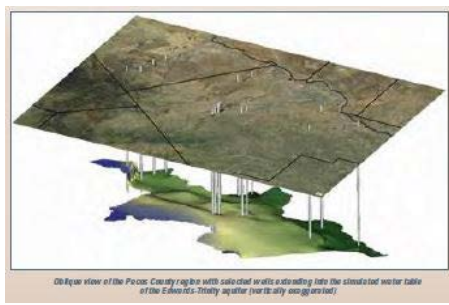

The USGS, in cooperation with the Middle Pecos Groundwater Conservation District, Pecos County, City of Fort Stockton, Brewster County, and Pecos County Water Control and Improvement District No. 1, completed a comprehensive, integrated analysis of available hydrogeologic data to develop a numerical groundwater-flow model of the Edwards-Trinity and related aquifers in parts of Brewster, Jeff Davis, Pecos, and Reeves Counties, Tex. The first phase of the study focused on collection of groundwater, surface-water, geochemical, geophysical, and geologic data in the study area and development of a geodatabase of historical and collected data. Data compiled in the first phase of the study were used to develop the conceptual hydrogeologic model in the second phase of the study. The third phase of the study involved the development and calibration of a numerical groundwater-flow model of the Edwards-Trinity aquifer to simulate historical groundwater conditions, as well as to project future conditions based on various groundwater-withdrawal scenarios.

- USGS publication for phase 1: http://pubs.usgs.gov/ds/678/

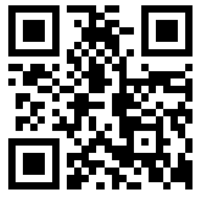

- USGS publication for phase 2: http://pubs.usgs.gov/ $\operatorname{sir} / 2012 / 5124 /$
- USGS publication for phase 3: http://pubs.usgs.gov/ $\operatorname{sir} / 2013 / 5228 /$
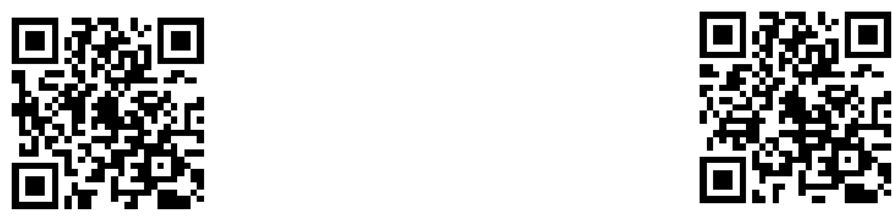

\section{Spatially Pooled Depth-Dependent Reservoir Storage, Elevation, and Water-Quality Data for Selected Reservoirs in Texas, January 1965-January 2010}

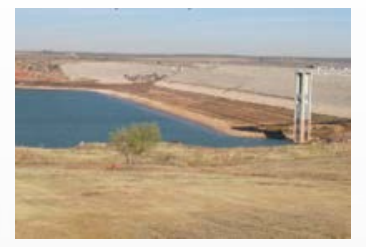

The USGS, in cooperation with Texas Tech University, constructed a sourceaggregated, spatially pooled, depth-dependent dataset of selected reservoir storage (daily and instantaneous values), reservoir elevation (daily and instantaneous values), and water-quality data from 59 surface-water reservoirs and lakes throughout Texas. Data were acquired from existing databases, spreadsheets, delimited text files, and hardcopy reports. Reservoir selection was based on various criteria including the availability of water-quality properties that might affect the trophic status of the reservoir and could also be important for understanding possible effects of climate change in the future.
- USGS publication and data: http://pubs.usgs.gov/ds/594/

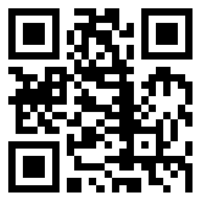

\section{Fish Assemblage Composition and Mesohabitat Use of the Rio Grande Silvery Minnow in the Rio Grande/Rio Bravo del Norte, Big Bend National Park, Texas, 2010-11}

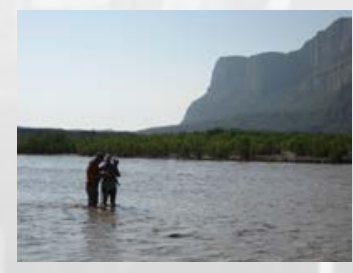

The USGS, in cooperation with the U.S. Fish and Wildlife Service and National Park Service, evaluated the physical characteristics and fish assemblage composition of mapped river mesohabitats at four sites on the Rio Grande/Rio Bravo del Norte in and near Big Bend National Park, Tex. The four sites used for the river habitat study were colocated with sites where the U.S. Fish and Wildlife Service has implemented an experimental reintroduction of Hybognathus amarus (Rio Grande silvery minnow), a federally listed endangered species, into part of the historical range of this species. In-channel river habitat was mapped at the mesohabitat scale over a range of seasonal streamflows. River habitat was mapped in the field by using a mobile geographic information system (GIS) platform and a differentially corrected Global Positioning System (GPS) unit. Physical-habitat characteristics were collected at the sites along with selected water-quality properties and fish assemblage composition.
- USGS publication: http://pubs.usgs.gov/ $\operatorname{sir} / 2013 / 5210 /$

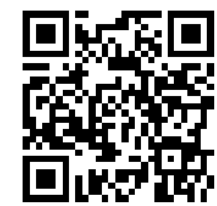




\section{Characterizing Drainage Area Watersheds of USGS Stream Gages in Texas To Build a Measurement Database for Empirical Flow Parameters}

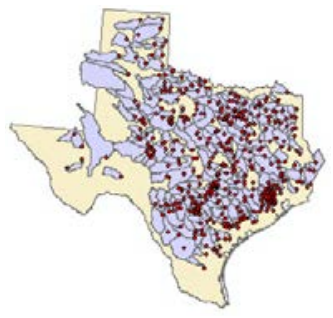

The USGS, in cooperation with the Texas Department of Transportation, evaluated the utility of different types of GIS-derived stream channel slopes for enhancing the prediction of mean velocity or discharge values from historical USGS discharge measurements associated with direct-runoff conditions in Texas. Semiautomated workflows involving custom Python programming language tools, GIS, and spatial datasets were used for deriving the physical characteristics of 437 gaged streams in Texas by delineating total drainage area watersheds in addition to main channel slope, proximal slope, main channel sinuosity ratio, stream order, land cover proportions, drainage

- Related journal article: http://dx.doi.org/10.1061/(ASCE) HE.1943-5584.0000715 density, and basin circulatory ratio.

\section{Geodatabase Design and Characteristics of Geologic Information for a Geodatabase of Selected Wells Penetrating the Austin Group in Central Bexar County, Texas, 2010}

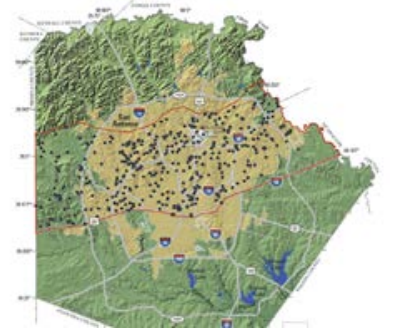

The USGS, in cooperation with the San Antonio Water System, developed a geodatabase of geologic and hydrogeologic information for selected wells penetrating the Austin Group in central Bexar County, Tex. The geologic and hydrogeologic information pertains to a 377-square-mile study area that encompasses central Bexar County. Data were compiled primarily from drillers' and borehole geophysical logs from Federal, State, and local agencies and published reports.

- USGS publication: http://pubs.usgs.gov/ds/522/

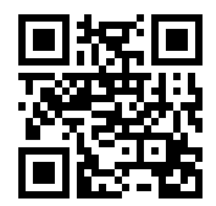

\section{Geodatabase and Characteristics of Springs Within and Surrounding the Trinity Aquifer Outcrops in Northern Bexar County, Texas, 2010-11}

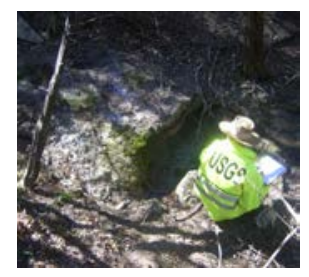

The USGS, in cooperation with the Trinity Glen Rose Groundwater Conservation District, the Edwards Aquifer Authority, and the San Antonio River Authority, developed a geodatabase of springs within and surrounding the Trinity aquifer outcrop in a 331-square-mile study area in northern Bexar County, Tex. The data used to develop the geodatabase were compiled from existing reports and databases, along with supplementary field data collected by the USGS between October 2010 and September 2011. Characteristics including the location, discharge, and water-quality data for known springs were stored in the geodatabase.
- USGS publication and geodatabase:

http://pubs.usgs.gov/ds/750/

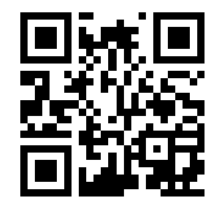

Any use of trade, product, or firm names is for descriptive purposes only and does not imply endorsement by the U.S. Government.
—By Thomas E. Burley

For additional information contact:

Director, Texas Water Science Center

U.S. Geological Survey

1505 Ferguson Lane

Austin, Texas 78754-4501

http://tx.usgs.gov/

2327-6916 (print)

ISSN 2327-6932 (online)

http://dx.doi.org/10.3133/fs20143117

Publishing support provided by

Lafayette Publishing Service Center 